\title{
REVIEWS
}

Adv Clin Exp Med 2015, 24, 1, 173-178

(C) Copyright by Wroclaw Medical University

DOI: $10.17219 /$ acem/38084

ISSN $1899-5276$

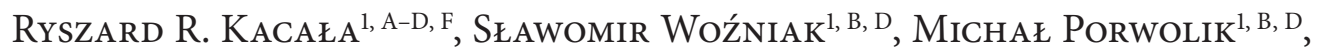

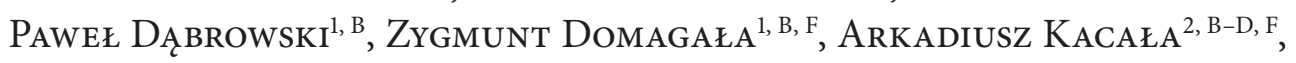
BOHDAN GWORYs ${ }^{1, B, E, F}$

\section{Remembrance of Professor Tadeusz Marciniak - Lviv Tradition in Wrocław}

${ }^{1}$ Department of Anatomy, Wroclaw Medical University, Poland

${ }^{2}$ Student, Faculty of Medicine, Wroclaw Medical University, Poland

A - research concept and design; $\mathbf{B}$ - collection and/or assembly of data; C - data analysis and interpretation;

$\mathbf{D}$ - writing the article; $\mathbf{E}$ - critical revision of the article; $\mathbf{F}$ - final approval of article; $\mathbf{G}$ - other

\begin{abstract}
After the seizure of Lviv by the Soviets, in the years 1944-1946, Tadeusz Marciniak worked in the Descriptive Anatomy Department in the State-Medical Institute of Lviv and also performed the function of the dean of the Medical Faculty. On receiving a proposal to assume the Chair of the Anatomy Department in Wrocław, he made the decision to leave Lviv. By July $2^{\text {nd }}, 1946$, prof. Tadeusz Marciniak had taken over the duties of full professor of the Descriptive Anatomy Department of the Medical Faculty of the University and the Technical College of Wrocław. On taking his job in Wrocław, prof. Marciniak undertook attempts to restore the worn out parts of the Anatomy Department building. Due to the lack of Polish manuals, he also took to the preparation of scripts for medical students. Professor Marciniak was a member of the Wrocław Section of the Polish Anthropological Association and a regular member of the Wroclaw Association of Science. His main scientific interests referred to the morphogenesis of the central nervous system and urinary system. He concentrated on circulatory system and muscular system tetralogies. Professor Marciniak also actively participated in administrative work at the university. In the years 1947-1948, he held the office of associate dean of the Medical Faculty, and till 1950 was a member of the Senate of the University and Technical College of Wrocław. In the years 1959-1962, he was a vice rector of the Medical University of Wrocław (Adv Clin Exp Med 2015, 24, 1, 173-178).
\end{abstract}

Key words: Tadeusz Marciniak, history of anatomy, Polish medical universities, University and Technical College of Wrocław, Jan Kazimierz University.

After the seizure of Lviv by the Soviets, in the years 1944-1946, Tadeusz Marciniak worked in the Descriptive Anatomy Department in the StateMedical Institute of Lviv. He also performed the function of the dean of the Medical Faculty. He was a very popular lecturer and delivered lectures for Polish students in their native language. He also ran courses of classes and lectures for Russian-speaking students. At that time, many pre-war assistants were engaged in the work of the Descriptive Anatomy Department. As professor Marciniak was a very good educator, he ran the classes with great commitment and was very popular among the students of the Medical Faculty. As a school overseer of Ukrainian young people, he took part in the life-restoring academic environment.

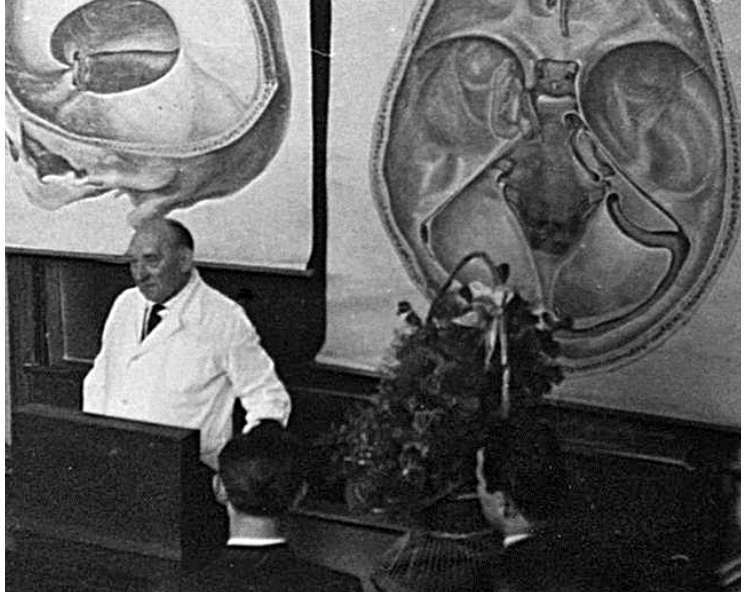

Fig. 1. Professor Marciniak in the lecture hall (from private archive of Ryszard R. Kacała) 


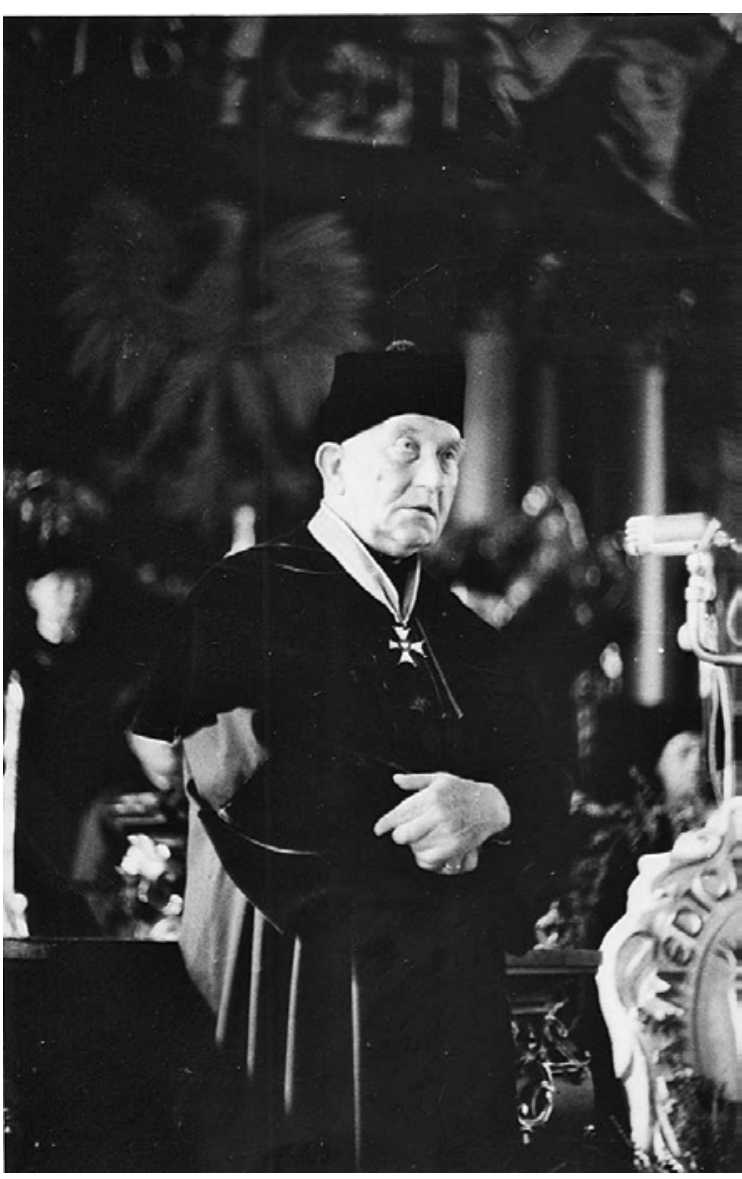

Fig. 2. Professor Marciniak at a university ceremony (from archive of Department of Anatomy, Wroclaw Medical University, Poland)

On receiving a proposal to assume the Chair of the Anatomy Department in Wrocław, he made the decision to leave Lviv in spring 1946 and began preparations to leave the city. Both his relationships and his popularity in the Lviv environment were so good that he remained unobstructed and was allowed to transport his assets to Wrocław. $\mathrm{He}$ received two carriages at his own disposal, into which he could pack all of his belongings. Cracow was the first step of the journey, where the professor stopped in a cloister and stayed there for some time, then in the middle of June he came to Wrocław. At first he lived in the building of the Anatomy Department, which was partly destroyed, and students helped him with the moving. House hunting began in order to find a place where the professor and his family could settle. At that time, Wiesław Krzysztoforski proved very helpful. The search did not last long and a house was found in Wrocław's Zacisze district, where professor Marciniak's son still lives. At the end of 1946, the professor and his family moved to a new place.

At first, starting in November 1945, anatomy was taught by professor Różycki, who got to Wrockaw from Poznań together with his own assistants. And it was he who had responsibility for the anatomy classes for the first year of medical students in post-war Wrocław. Professor Marciniak gradually took over the anatomy classes starting from autumn 1946.

A document dated July $2^{\text {nd }}, 1946$ and signed by the rector of the University and the Technical College of Wrocław stated that since the day June $1^{\text {st }}$, 1946, professor Tadeusz Marciniak had taken over the duties of full professor of the Descriptive Anatomy Department of the Medical Faculty with a " $4^{\text {th }}$ salary level". The appointment was confirmed by the Ministry of Education [1].

On the basis of a document dated December $20^{\text {th }}, 1946$, by the decision of the President of the National Council, Tadeusz Marciniak was appointed to full professor of Descriptive Anatomy in the Medical Faculty along with the Pharmaceutical Division of the University in Wrocław. The document was also signed by the Prime Minister and the Minister of Education [2]

In a document dated January $21^{\text {st }}, 1947$, the Minister of Education defines the duties of a professor within the field of anatomy teaching: at least 5 hours of lectures and 2 hours of classes per week for the whole of the academic year or according to the rule that 2 hours of exercises go along with 1 hour of lecture [3].

In a document dated December $18^{\text {th }}, 1947$, Professor Marciniak became a school inspector of The Students Brotherhood at the University and the Technical College in Wrocław by the Senate of the University and the Technical College of Wrocław [4].

Working conditions in the Anatomy Department were extremely difficult because of the damage to the building and the loss of property resulting from raids. On taking his job in Wrocław, professor Marciniak undertook attempts to restore worn out parts of the Anatomy Department building and began raising its new alette. However, the most essential element was the prosectorium restoration. Quite simultaneously, efforts were made to maintain and protect the preserved museum collection as well as the collection of the library, which had been so richly equipped by the Germans. The restoration of the building lasted up to the year 1948. Lectures took place in the partly renovated room of the Anatomy Department Laboratories of Anthropology, Histology, Plastic Materials and Technique as well as of Anatomy and Radiology were founded. The elaboration and preparation of about 2300 boards with anatomical drawings and numerous Polish explanations were very important for didactics. Part of the didactic materials, e.g. boards and pictures, originated from the period before the Second World War. In the first period, in the professor's activity in the 
Anatomy Department, he cooperated mainly with Romuald Janda.

A lack of manuals for medical students was an essential problem. Beyond the permanent employees, volunteers (senior students) ran classes. Due to the lack of Polish manuals, German or Russian books and scripts were used but the main source of knowledge was professor Marciniak's lectures. At the same time, professor Marciniak took to the preparation of scripts for medical students. Scripts on normal anatomy came into being in the first 10 years of his activity in the Anatomy Department In the years 1949-1958, 8 editions of 7 -volume scripts were published. They were an introduction to the preparation of the 3 -volume manual "Normal Anatomy of Humans", the crowning achievement of professor Tadeusz Marciniak's didactic work [5].

Professor Marciniak also gave anatomy lectures for anthropology students in the Faculty of Sciences of the University of Wrocław, actively participated in the training of nurses and midwives in the medical schools of Wrocław and taught anatomy for students of the College of Arts.

A lack of literature was the most troubling problem in teaching anatomy; however the lectures given by professor Marciniak were an important and substantial aid for students in their education process. A large number of boards and large-scale illustrations which remained from German times were used by the professor during his prelections. An example of such an interesting public presentation is the lecture on fertilization presented to candidates for medical studies in 1946.

A letter from a student, Adelajda Torówna, in which she wishes her professor a Merry Christmas and thanks him for very special and demanding classes, evokes the unique atmosphere of those times [15].

On April 20 $0^{\text {th }}$, 1948, professor Marciniak became qualified to the fellowship of members of the Wrocław Section of the Polish Anthropological Association and on March $1^{\text {st }}, 1948$, he was appointed as a regular member of the Wrocław Association of Science and began his activity in it [6].

At that time the professor made efforts to create the Polish Anatomists Association. He was convinced that this was absolutely indispensable for the functioning and development of anatomy as a science in a renaissance country. For this purpose, he prepared a special pronouncement in which he suggested the necessity of such a companionship appointment. He wrote about this to his friends during the period when five Polish universities lived to see the appointment of Anatomy departments, the opening of a sixth one in Lublin was close but was constituted into the National Dental Institute, and two departments were appointed in veterinary colleges, with many others of relative activity coming into being.

In this situation, there was an urgent need to form a central organ representing anatomists' interests. In the professor's opinion, it was high time to provide the foundations for the future Anatomical Association. This document proves the professor's incredible activity in the field of cooperation with other academic centers in the country.

At that time, the professor very actively and closely cooperated with the students of Wrocław, and it was strictly connected with his duties as a school inspector. In a letter dated March $23^{\text {rd }}$, 1950, from the Board of the Students Brotherhood of the University and Technical College of Wrocław, the professor was invited to the last extended plenary session, the effect of which was a resolution proclaiming the dissolution of the Brotherhood on the basis of the authorities' decision concerning the separation of the students' support organization [7].

The professor's incredible popularity among students as well as the great interest drawn by his lectures brought forth the new tradition of delivering a lecture for students graduating from the university and beginning the job of doctor. Professor Marciniak's lectures always attracted a full auditorium. During his activity in the Anatomy Department, there were about 100 assistants who subsequently specialized in a variety of medical domains, and very many of them stayed at the university to lay the foundation for a number of departments and university hospitals.

During his lectures, professor Marciniak was, on the one hand, very merry, witty and bluff, but on the other hand turned out to be awe-inspiring. He was very popular for his sarcastic sense of humor, so his colleagues tried to avoid being the object of his jokes.

Lviv and the picture of Our Lady always evoked his sentiment, and this fact was eagerly exploited by students, who often placed photos of Lviv or pictures of the Virgin Mary in their student's books.

At that time, doctor Czesław Niżankowski, who lived in the building of the Collegium Anatomicum, was his main aide. Professor Marciniak stood for Jena terminology so he eagerly propagated new anatomical naming and published number of papers devoted to this issue. The papers and scripts were dictated to his assistants and copied with the use of a roneograph by a secretary who, at that time, was mainly a typist and administrative assistant.

In the cellarage of the Anatomy Department building, there were about 200 preserved human corpses originating from German times, which made it possible to carry out dissection classes with 
the students. The assistants' duties were to preserve the corpses and the preparations were regular.

The museum, which was renovated in a very short time, was a sort of sanctuary for the professor, and no one could enter it. Starting from 1948, the Anatomy Department was practically restored and classes were run there regularly. However, living in a ruined city was not easy, and professor Marciniak was seeking an opportunity to leave Wrockaw. The opportunity appeared at the beginning of 1949. From a document dated July $15^{\text {th }}$, 1949, and addressed to professor Jan Zaorski, we may assume that professor Tadeusz Marciniak accepted the offer to become the head of the Normal Anatomy Department of the University of Warsaw [8]. In the same document, he explained that he had loyally informed the Faculty Council about his decision. On February $18^{\text {th }}$, during the Council meeting he was asked to reconsider his decision and the Faculty Dean declared his intention to make every possible effort to keep professor Marciniak in Wrocław. So professor Marciniak again reported his change of heart to professor Zaorski, and eventually, on February $21^{\text {st }}, 1949$, professor Marciniak informed the Dean of the Medical Faculty, professor Tadeusz Baranowski, and withdrew his candidacy from the election of the head of the Normal Anatomy Department of Warsaw University [9].

The initial acceptance of the proposal of the appointment to the head of the Normal Anatomy Department of the University of Warsaw proved that, in the first period of his work, professor Marciniak was not fully convinced that this city was his final destination. Dean Baranowski's determination to keep him in Wrocław stopped professor Marciniak from changing his place of work.

Professor Marciniak also actively participated in administrative works at the university. In the years 1947-1948, he held the office of the Associate Dean of the Medical Faculty, and till 1950, was a member of the Senate of the University and Technical College of Wrocław. In the years 1959-1962 , he was a vice rector for scientific affairs of the Medical University of Wrocław [10]. He also took an active role in the foundation of the Physical Education College in Wrocław in which he acceded to the office of the head of the Biomechanics Department. In accordance with the Minister of Education's appointment [11], in this college, in the years 1962-1963, he held the office of the Rector [2].

Except for his academic duties, fulfilled at the Medical University and Physical Education College, professor Tadeusz Marciniak worked in a number of scientific associations. In the years 1958-1960, he was the General Secretary of the
Wrocław Scientific Association and then the chairman of the Board of Control of this association. He was also the president of the Wrocław Section of the Anatomical Association and he also worked as the chairman of the Scientific Board in the Anthropology Institute of the Polish Academy of Sciences in the years 1961-1963. Among other posts, he was a member of the General Management of the Polish Anatomical Association in Warsaw and a member of a commission responsible for science at the Main Committee of Physical Culture and Tourism in Warsaw.

Professor Marciniak's main interests referred to the morphogenesis of the central nervous system and urinary system. He also concentrated on the circulatory system and muscular system tetralogies. He was very much concerned with anatomical terminology and stood for Jena nomenclature, making it popular among medical students.

From the very beginning of his activity in Wrocław, professor Marciniak had the classes and lectures for students at heart. Due to the deficiency of manuals in Polish, he started work on writing scripts for medical students and in the years 1949-1958, 8 editions of his 7-volume scripts were published. The scripts were just the introduction to the preparation of the 3-volume textbook, "Normal Anatomy of Humans", which was the crowning achievement of professor Marciniak's didactic work. Professor Marciniak also gave anatomy lectures for the anthropology students of the Faculty of Environmental sciences of the University of Wrocław, took part in the training of nurses and midwives in medical schools in Wrocław and taught anatomy in the National College of Arts.

"Nephrometry in Humans" was the main publication achievement in the post war period of the professor's work. This monograph described the kidney structure, size and density and was based on the largest amount of material collected in world literature at that time. Based on numerous calculations presented in over one hundred tables and several dozen figures, Tadeusz Marciniak presented the most characteristic types of kidney structure.

For his exceptional contribution to science and didactics, Tadeusz Marciniak was knighted with the Commander's Cross of Polonia Restituta [13, 14]. On August 26 $6^{\text {th }}, 1966$, one month before he was set to retire, Tadeusz Marciniak died in Warsaw, after a severe disease. The professor's disease was connected with a developing carcinoma of the large intestine. Professor Marciniak had not lived to see his retirement and died in the period of his full research and didactic activity. One should remember that on October $20^{\text {th }}, 1976$, in the Normal Anatomy Department, Rector Stanisław Iwankiewicz, in the presence of the Head of the 
Department, professor Czesław Niżankowski, displayed a commemorative tablet devoted to professor Marciniak's work.

Tadeusz Marciniak was a deeply religious person and he very regularly and actively participated in church services. Among the many preserved documents, there is a tapescript of a speech devoted to the matters of the clergy, which had probably been delivered during some meeting with ecclesiasts.

Being an active researcher for so many years, he had never been a Communist Party member so he was subjected to intense surveillance by the Security Service, which can be followed in a series of documents collected in the Medical University archives, however his nonparty adherence was often commented there.

During his work at the Medical Faculty, Tadeusz Marciniak was a tutor of two postdoctoral qualifications: by Tadeusz Wasilewski from Łódź in 1947: "Constitutional Types of the Calf Triceps" and by Czesław Niżankowski from Wrocław in 1961: "Typology of Human Cardiac Coronary Vessels". He was also a supervisor of six doctoral theses which originated from the Normal Anatomy Department. The candidates for a doctoral degree were professor Tadeusz Marciniak's longtime assistants. The doctoral dissertations, under the direction of the professor, were defended by: Mieczysław Ziółkowski in 1964 - "The Abdominal Ostium of the Oviduct with the Regard of the Structural Typology of Caruncles"; in 1965, by Paweł Bergman - "The Variability of the Hand in the Population of Poland"; in 1965, by Jadwiga Malucin-Szeler - "Sizes and Shapes of Fontanels with Reference to the Skull Sizes in Children"; by Jerzy Szybejko in 1965 - "On the Innervation of the Short Head of the Biceps in Humans"; by Edward Rosengarten in 1965 - "The Prevalence of Sesamoid Bones of the Hand in the Population of Poland"; and by Alexander Malinowski in 1966 - "The Shape and Size of the Calcification the Scaffolding of Larynx and Trachea Depending on the Age and Sex in Polish Population".

\section{References}

[1] Document dated July 2 $2^{\text {nd }}, 1946$, with the information sent by the dean of the Medical Faculty, Prof. Grabowski, about Prof. Tadeusz Marciniak, as a full professor, taking over the post of the Head of the Anatomy Dept. Private archive of professor Roman Marciniak.

[2] Document dated December $20^{\text {th }}, 1946$, declaring that the president of the National Council appoints the citizen, Tadeusz Marciniak, the title of full professor of descriptive anatomy at the Medical Faculty with the Pharmaceutical Section of the University of Wrocław; the president of the National Council, Bolesław Bierut. Private archive of professor Roman Marciniak.

[3] Document dated January $21^{\text {st }}, 1947$, defining a professor's duties in the field of anatomy teaching due to the appointment of Tadeusz Marciniak to full professor, with the decree of the President of the National Council. Private archive of professor Roman Marciniak.

[4] Document dated December $18^{\text {th }}, 1947$, a paper to Tadeusz Marciniak, to the Manager of the University and the Technical College about the appointment of Tadeusz Marciniak to school inspector of the Brotherhood of Students of the University and Technical College of Wrocław. Private archive of professor Roman Marciniak.

[5] Document dated April 21 $1^{\text {st }}, 1953$ from the Education Department of the Ministry of Health to the rector of the Medical University of Wrocław. The manager of the department, Prof. Rogiński; in response to a letter from the rector, the Education Department of the Ministry of Health accepts Prof. Tadeusz Marciniak taking over script publishing affairs and grants him monthly earnings, with reference to a paper dated January $23^{\text {rd }}, 1953$ defining April $1^{\text {st }}$ as officiation onset. Private archive of professor Roman Marciniak.

[6] Document in the form of a letter from the Brotherhood of Students of the University and Technical College of Wrocław dated March $23^{\text {rd }}, 1950$ to the School Inspector of the Brotherhood, Prof. Tadeusz Marciniak, with the information that the last Extended Presidium of the Committee will take place on March $27^{\text {th }}$, at $7 \mathrm{pm}$ at 34 Szewska St. At this session the resolution would be taken about dissolution of the association of the Brotherhood of Students. Signed by the president, Józef Kuziewicz. Private archive of professor Roman Marciniak.

[7] Document dated March 1 ${ }^{\text {st }}, 1948$ from the Wrocław Scientific Association about the appointment of Prof. Marciniak to full member of the Wrocław Scientific Association. Private archive of professor Roman Marciniak.

[8] Document dated February $15^{\text {th }}, 1949$, from Tadeusz Marciniak to Prof. Zaorski informing him about the former's intention to apply to the post of the head of the Descriptive Anatomy Dept. and the request for consent to take the post of the head of the Normal Anatomy Dept. Date: Feb. $15^{\text {th }}, 1949$. Private archive of professor Roman Marciniak.

[9] Document dated February 21 st, 1949, a letter from Tadeusz Marciniak to the Dean of the Medical Faculty, Prof. Tadeusz Baranowski, informing him about withdrawing his candidacy from the post of the head of the Normal Anatomy Dept. at the University of Warsaw. Private archive of professor Roman Marciniak.

[10] Copy of a document dated June $12^{\text {th }}, 1959$ informing, "I declare that I have taken note of the election of Prof. Boguslaw Dobrański to rector and Prof. Aleksander Kleczewski, Prof. Tadeusz Marciniak and Prof. Tadeusz Kudarbiński to associate rectors of the Medical University of Wrocław, for the period of 3 years starting from September $1^{\text {st }}, 1959$, Prof. Tadeusz Marciniak, the associate rector for research affairs. Private archive of professor Roman Marciniak. 
[11] Document dated February $9^{\text {th }}, 1962$, from the Ministry of Health and Social Welfare to Tadeusz Marciniak, permitting him to do extra paid regular employment in the College of Physical Education in Wrocław with the post of head of the Biomechanics Dept. till September $30^{\text {th }}$, 1963. Private archive of professor Roman Marciniak.

[12] Document dated October $13^{\text {th }}, 1962$, informing Prof. Tadeusz Marciniak that the Rector's College, on the occasion of the inauguration of the academic year 1962-1963 in the Medical University of Wrocław, due to his incredible contributions to research and didactic development, had resolved prize money in the amount of 4000 PLN be awarded to him and looked forward to further successful research work. Rector Aleksander Kleczeński. The letter to the Minister of Health and Social Welfare dated August $16^{\text {th }}, 1963$, for a further permit for extra classes in the College of Physical Education where, so far, Prof. Marciniak had been the head of the Biomechanics Dept. and where he was to be elected the rector in the academic year 1962-1963. Private archive of professor Roman Marciniak.

[13] Identity card no. 1-37076, dated July 22 ${ }^{\text {nd }}, 1964$, concerning the Resolution of the National Council awarding Prof. Tadeusz Marciniak the honor of the Commander's Cross of Polonia Restituta. Secret document: Recommendation to award Prof. Marciniak with the Commander's Cross of Polonia Restituta, no date mentioned. Private archive of professor Roman Marciniak.

[14] Letter dated April 30 th 1966 and sent to Prof. Tadeusz Marciniak: "With relation to retirement, I hereby thank you for many long years of work in Polish Republic University Education and acknowledge gratitude and admiration for your research and didactic activity connected with the education of Polish intelligentsia and young research workers. The Minister of Health and the Social Welfare". Private archive of professor Roman Marciniak.

[15] Typescript of the lecture for candidates to the first year of medical studies in the year 1946 - "On Fertilization". Private archive of professor Roman Marciniak.

\section{Address for correspondence:}

Ryszard R. Kacała

Department of Anatomy

Wroclaw Medical University

Chałubinskiego 6a

50-368 Wroclaw

Poland

Tel.: +48 606917373

E-mail: rkacala@cornetis.pl

Conflict of interest: None declared

Received: 20.05 .2013

Revised: 27.05.2013

Accepted: 12.01.2015 